Anna Maria Karczewska

DOI: 10.15290/cr.2015.11.4.01

University of Białystok

\title{
Against dechoukaj: the trauma of Haiti in Edwidge Danticat's The Dew Breaker
}

\begin{abstract}
Diaspora writers add to a long American literary tradition of engaging with political issues, a rich body of literature focused on themes of occupation, persecution, dictatorship, repression and trauma. This paper focuses on a political protest in the form of personal narrative of Haitians whose forgotten or ignored stories were reinscribed by Haitian-American author Edwidge Danticat in The Dew Breaker (2004).

The paper examines the representation of Haiti's history and the collective experience of violence and trauma during the Duvaliers' dictatorship, and revisits the terror instilled by a paramilitary police - the Tonton Macoutes. In The Dew Breaker Danticat offers a compelling portrait of individuals haunted by pain, trauma and loss. Their stories function as a testimony of the generations of Haitians who experienced abuses and atrocities committed during the era of "Papa Doc" and "Baby Doc". The book presents the effects of trauma on the individuals and the community, shows what is destroyed by trauma and offers solutions to deal with the traumatic experience. The aim of the paper is to analyze how The Dew Breaker gives a unique access to Haitian history, how it deals with its legacy of violence, how the subaltern articulate their traumas and how literature creates a voice for victims of political violence and psychological terror.
\end{abstract}

Keywords: Edwidge Danticat, trauma, Haiti, dictatorship, Francois Duvalier, Jean Claude Duvalier, Tonton Macoutes

Who cares why, at this distance? A disaster is a disaster; those hurt by it remain hurt, those killed remain killed, the rubble remains rubble (Atwood 1993: 3).

Literature often confronts official discourse critically and harshly, and rewrites that discourse and history to include the perspectives of the marginalized or excluded. It explores social questions and often speaks on behalf of a "collective unaware and largely silenced and buried under a heap of false and perverted rhetoric" (Ramirez in Craft, 10). Contemporary authors create new genres and try to move beyond existing national, traditional, globally-used forms, which are simultaneously political and literary. This type of writing makes a political problem fundamental to the story and serves as an intermediate step in a process directed toward producing change in the world, pro- 
moting justice by continuous examination of personal histories of all the people and discourses ${ }^{1}$. David Shields, in his book Reality Hunger (2010), argues that contemporary fiction is enlivened by efforts to make the readers "interested, empathetic, questioning, or even antipathetic to what they are seeing" (Shields 2010: 51). New hybrid genres, which combine different stylistic categories open up debates and stimulate discussion.

Haitian-American author Edwidge Danticat reinscribed forgotten and often ignored stories of Haitians in the hybrid form of personal narrative entitled The Dew Breaker (2004). The book offers a compelling portrait of individuals haunted by pain, trauma and loss. Their stories function as a testimony of the generations of Haitians who experienced abuses and atrocities committed during the era of "Papa Doc" and "Baby Doc". The paper focuses on the effects of trauma on the individuals and the community, and the healing of trauma as mediated by Danticat's work. It examines the representation of Haiti's history and the collective experience of violence during the Duvaliers' dictatorship, and revisits the terror instilled by a paramilitary police - the Tonton Macoutes. The aim of the paper is to analyze how The Dew Breaker gives unique access to Haitian history, how it deals with its legacy of violence, and how the subaltern communicate their traumas and heal them.

To argue the role of literature in creating a voice for victims of political violence and psychological terror, the historical context of The Dew Breaker needs to be discussed. In 1957 a fifty-yearold country doctor won elections in Haiti and soon turned his presidency into a fourteen-year dictatorship. Francois Duvalier, as he is referred to here, was known to the world as 'Papa Doc'2. In his quest for absolute power he forced his presidency-for-life, and introduced an authoritarian regime. Duvalierism was known for its endemic brutality, and it was a period of terror and hysteria. Duvalier's Haiti was a byword for state terrorism, corruption, extortion and underdevelopment. Governed by a tyrant voodooist and his irrational personal whims, the Caribbean republic became a social and economic ruin, the poorest country in the Western hemisphere, where people had a life expectancy of forty years. The terror was institutionalized through Duvalier's personal armed civilian militia, which infiltrated every area of Haitian society (Abbott 1988: 98-105). The Volunteers of National Security were known almost exclusively as the Tonton Macoutes ${ }^{3}$, and constituted an effective network of repression. They inherited the name from the Haitian folk belief in a boogeyman who prowls at night to hunt down errant children and kidnaps them in his straw satchel bag (macoute). The Macoutes acted as political cadres, secret police and instruments of terror. The members of the Macoutes came from the most disadvantaged classes. They were often

1 For more discussion on this subject see: Toward the Geopolitical Novel. U.S. Fiction in the Twenty-First Century by Caren Irr, 2013, Columbia University Press.

2 Familiar names have often been given to Haitian presidents to reflect the mixture of authority and paternalism which surrounds the office. The element of paternalism, where the dictator appears either fatherly or avuncular, acts as an emollient for their horrendous crimes.

3 The Creole phrase Tonton Macoute means Uncle gunny sack. 
illiterate criminals who were elevated to positions of power. Not only did they execute Duvaliers' orders, but they also committed crimes of their own volition. The reign of terror and the process of Macoutization infested every niche of the society (Ferguson 1987: 40-41, 52-53) ${ }^{4}$. The sadism of the Macoutes and the corruption that legitimized them were exposed by Graham Greene in his powerful novel The Comedians (1966), which was banned in Haiti. The county was, in the words of the author, "The Nightmare Republic" (Greene 2005: 32).

The regime continued when power was handed to Papa Doc's feckless 19-year-old son Jean Claude (Baby Doc) $)^{5}$ With another fifteen years of Duvalier rule, Haiti sank further into agricultural and economic ruin, despair, numbing poverty, and sleepy decay. Finally, people's desire for change and a new social order created an ad hoc movement. In 1986 massive waves of protests,

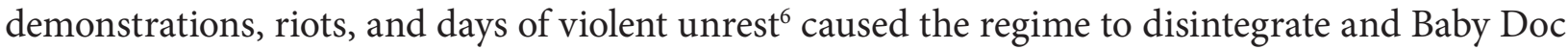
was forced to flee the country. Duvalier's departure was followed by a gruesome episode which Haitians called 'operation dechoukaj' (operation uproot in Haitian Creole). It was the process of ridding the country of Duvalierism, which meant destroying buildings and the Duvalier family mausoleum, at the same time erasing the dynasty from the country's architecture. Dechoukaj also implemented hideous executions of Tonton Macoutes (Wilentz 2010).

Edwidge Danticat engages with such socially-defining events of her homeland's history in her book The Dew Breaker. The author investigates the violence of those times, its indelible legacy and lingering effects in the collective consciousness. The books' fictionalized stories are, in some ways, a collage of real events, so The Dew Breaker displays the collective memory that haunts Haitians both in Haiti and in the diaspora.

The Dew Breaker is not exactly a novel. It is a short story cycle, a memoir, testimonio, a hybrid form of life writing. The story is told from multiple points of view. The text also contains resonant cultural sources. There are fragments from Life and Le Monde, and allusions to Graham Greene's The Comedians. In this way Danticat translates her country's traumatic history into a different form, an intertext that, in a sense, converses with the aforementioned elements and fragments. The author moves easily back and forth in time and place, and combines multiple tales "that come together like jigsaw-puzzle pieces to create a picture of one man's terrible history and his and his victims' afterlife" (Kakutani 2014). Some of the puzzle pieces are missing, the stories are sketchy,

\footnotetext{
4 "The Duvaliers [...] claimed more than 40,000 human lives. They developed a coercion network made up of the Macoutes, the Haitian army, right-wing paramilitary groups, and rural magistrates to prevent civilian resistance to authoritarian rule and repress political opposition activity, while censoring or castigating any critique of the state". See: Steeve Coupeau, p.95.

5 The nickname was the scornful invention of foreign journalists.

6 The seeds of the downfall of the Duvalier regime can be found in its incapacity to deliver economic prosperity and political freedom, and its inability to reform public finances and to deliver on the basic demands of the Haitian population; pro-democracy groups were encouraged by the speech of Pope John Paul II upon his arrival in Port-au-Prince, and radio stations raised public awareness; a fever epidemic among porcine livestock and repressions of hunger riots provoked further incentives to revolt. See: S. Coupeau, p.105-106.
} 
the cinematic plot resembles evocative snapshots, the protagonists' memories are broken and discontinuous. Apparent randomness has a clear design, as Danticat, by means of her limpid, understated prose and looping structure, recreates reactions to the traumatic events (Kakutani 2014). What is more, "the fragmented form of the text mirrors the fragmented and scarred Haitian people, whose country has been marked by political instability since its founding in 1804" (Bellamy 2012: 177-197). The tales in The Dew Breaker are stories of political and personal intersection. They present the effects of trauma both on the individual and the community, and they give a voice to victims of political violence and psychological terror. They revisit traumatic memory and try to help understand the processes of victimization, remembering, witnessing, and recovery. Trauma narratives are sites of social critique. They reconstruct histories, promote new forms of political action, open up new international debates on human rights. According to Gayatri Spivak, each great narrative is a program "which tells how social justice is to be achieved" (Spivak 1990: 19). In this connection The Dew Breaker may also stir the conscience of people, especially in view of the fact that it was inspired by newspaper articles, in recent years, concerning many former Haitian torturers living in the United States. In 2003 many of them were deported to Haiti by the U.S. Department of Homeland Security (Valbrun 2004: 42-43). ${ }^{7}$

The Dew Breaker is a series of nine interrelated short stories that mirror the lives of individuals united by pain, trauma and loss, and who try to voice their past suffering. Danticat depicts the lives affected by a 'dew breaker's, a torturer of Haitian dissidents during the Duvaliers' reign. The eponymous dew breaker remains nameless throughout the book because, as the author suggests, there were many people like him. The book's other characters, his victims, intermingle with real people as well (Danticat 2004). Other protagonists are members of the dew breaker's family, his former victims and their family members, who are also haunted by the period that left no-one untouched or unharmed. The protagonists share the burden of the past that left them with marred bodies, broken families or destroyed hopes. Mariselle's husband (“The Funeral Singer”) ${ }^{9}$ was murdered after he drew an unfavorable picture of the president. Beatrice ("The Bridal Seamstress") was the victim of a Tonton Macoute who "whipped the bottom of [her] feet until they bled. Then he made [her] walk home, barefoot. On tar roads. In the hot sun. At high noon" (Danticat 2005: 132); Rezia ("The Funaral Singer"), when she was a girl, was raped by a "uniformed man", who must have been the Tonton Macoute; Freda's father (“The Funeral Singer") committed suicide after he was tortured and his property was confiscated:

\footnotetext{
7 To date, none of the Macoutes were imprisoned for their actions. Their victims have waited in vain for justice and even seen former Duvalierist officials recycled in succeeding, supposedly “democratic," governments.

8 Dew breaker was a name given to members of the Tonton Macoutes ("The term "dew breaker" is a Creole expression for a representative of the dictatorship in a rural area- a person with free reign in the area, acting as judge, jury and executioner. A dew breaker comes in the early morning to claim his victims, breaking the dew on the grass.") See: http://www.theatlantic.com/magazine/archive/2004/06/grappling-with-haiti-s-beasts/303391/
}

9 The title in the brackets refers to a particular story from The Dew Breaker. 
He'd had a fishstall at the market. One day, one macoute came to take it over and another one took my father away. When my father returned, he didn't have a tooth left in his mouth. In one night, they'd turned him into an old, ugly man. The next night he took his boat out to sea and, with a mouth full of blood, vanished forever (Danticat 2005: 172).

Danticat shows here a double impact of the loss of property and, far more important, family in the space of one day. The protagonist of the story "Monkey Tails" also loses his father, which makes him "part of a generation of mostly fatherless boys" (Danticat 2005: 141) as the fathers either died in the dictatorship's prisons or abandoned their families to serve the regime. The oppressive system of the Duvaliers touched the whole population of Haitians. Even those who left the country or were only indirectly touched by the torturers' cruelties do not seem totally free from the violent legacy. There are passive victims of traumatic events who suffer the trauma of being raised by traumatized parents, or by living in close proximity to the pain of people who survived massive historical terror. There is also a third group of people who suffer on an individual and national level - that of perpetrators and those related to them. Danticat shows that they are not excluded from the collective trauma; they live with the burden of the past and their guilt. All of them are socially bound by their personal experience, which is also connected with the history of the Haitian community. They are "men and women whose tremendous agonies filled every blank space in their lives. [...] men and women chasing fragments of themselves long lost to others. [...] palannits, night talkers, people who wet their beds, not with urine but with words" (Danticat :139$138,98)$. They find an immense void in their lives. They are full of unutterable grief and repressed memories. What the protagonists experienced appears accessible outside the realms of their conscious memory. They communicate their traumatic experience in nightmare, hallucination and unwanted repetition, only then do they relieve and confess. (Ibarrola Armendariz 2010: 32). Danticat appears to be perfectly aware of what Cathy Caruth, who builds her theory on the work of contemporary clinical trauma specialists Judith Herman and Bessel van der Kolk, claims. Caruth maintains that trauma causes amnesia and is ineffable ${ }^{10}$, that the reactions to the traumatic events are not to be found in the immediate aftermath of the atrocities experienced but, rather, "occur in the often delayed, uncontrolled repetitive appearance of hallucinations and other intrusive phenomena" (Caruth 1996: 11). The traumatic past determines the everyday life of the book's protagonists, and manifests itself in the subconscious with a tendency to resurface in the character's story or haunting memories. Dany ("Night Talkers"), who witnessed his parents' death at the hands of the 'dew breaker', seeks revenge and is obsessed with finding the murderer, yet the question appears of whether vengeance can bring peace of mind. Beatrice ("Bridal Seamstress") suffers from

10 the suggestion that one may forget—or fail to accurately describe-trauma is a foundational insight for the first wave of literary trauma theorists, among them Geoffrey Hartman, Shoshana Felman, and Cathy Caruth. However, newer clinical studies on the psychology of trauma have challenged the theories on which Caruth relies. According to Harvard's Richard McNally, traumatic amnesia is a myth, and while victims may choose not to speak of their traumas, there is little evidence that they cannot. see: Joshua Pederson, Speak, Trauma: Toward a Revised Understanding of Literary Trauma Theory. 
paranoia. She never managed to fully recover from the psychic wounds she received in her youth. She imagines her torturer following her everywhere she moves. Anne ("The Book of Miracles") suffers the emotional consequences of her marriage to a former Macoute. Nadine ("Water Child") refuses to interact with her co-workers or communicate with her parents in Haiti. According to Herman, traumatic events call into question basic human relationships. They breach the attachments of family, friendship, love, and community. They shatter the construction of the self that is formed and sustained in relation to others (Bellamy 2012: 187-189).

Each chapter in the book discusses a different victim's struggle, while three core chapters ("The Dew Breaker", “The Book of the Dead”, “The Book of Miracles”) concern the dew breaker's family and Ka's (the dew breaker's daughter) discovery of her father's past as a prison guard. The reader meets the dew breaker as an old, peaceful man and a good father. When the story unfolds, the dew breaker's actions, their effects on various characters, and his old identity are revealed:

The way he acted at the inquisitions in his own private cell at Casernes eventually earned him a lofty reputation among his peers. He was the one who came up with the most physically and psychologically taxing trials for the prisoners in his block. He was suffering, he knew it now, from what one of his most famous victims, the novelist Jacques Alexis, had written was the greatest hazard of the job [...] It was becoming like any other job. He liked questioning the prisoners, teaching them to play zo and bezik, stapling clothespins to their ears as they lost and removing them as he let them win, convincing them that their false victories would save their lives. He liked to paddle them with braided cowhide, stand on their cracking backs and jump up and down like a drunk on a trampoline, pound a rock on the protruding bone behind their earlobes until they couldn't hear the orders he was shouting at them, tie blocks of concrete to the end of sisal ropes and balance them off their testicles if they were men or their breasts if they were women (Danticat 2005: 197-198).

A merciless sadist who worked with ruthless efficiency remade himself into a kindly landlord and barber who lives a modest life in Brooklyn, New York. He feels remorse, guilt that manifests in his nightmares, and he lives with the burden of the past and his actions. Danticat, showing a change that can occur in a perpetrator, constructs a more balanced portrait of a man who, as a powerless, impressionable boy joined the Tonton Macoutes. In later years his position was reversed when he mishandled his orders, at a certain point in his career as a torturer, killing the preacher who tore his cheek with a piece of a broken wooden chair. The narrative records the dying preacher's thoughts:

The battle would be someone else's to fight from now. And yet he had not been completely defeated. The wound on the fat man's face wasn't what he had hoped; he hadn't blinded him or removed some of his teeth, but at least he'd left a mark on him, a brand that he would carry for the rest of his life. Every time he looked in the mirror, he would have to confront this mark and remember him. Whenever people asked what happened to his face, he would have to tell a lie, a lie that would further remind him of the truth (Danticat 2005: 227-228). 
A great paradox of the book is that the perpetrator carries the most visible sign of the atrocities he committed in the past. The dew breaker lives with constant guilt and self-loathing, and is tortured by nightmares. Painting a portrait of the former Tonton Macoute, Danticat shows how the effects of the Duvalier dictatorship were equally observable in the victims and supporters of the regime; that the line between hunter and prey in Duvalier-era Haiti was highly situational. When seen in this light, the former Macoute is humanized. He is portrayed as a multi-faceted person, and the duality of his character makes it impossible to judge him easily.

The abuses and atrocities committed in Haiti are a heavy burden for victims, victimizers and people related to them. The story "Monkey Tails" takes the reader to February 7, 1986 in Haiti, while Baby Doc was escaping to France. The protagonist of the story, Michel, was doubly traumatized because that day, for the last time, he saw his best friend, who turned out to be the son of a Tonton Macoute. The fervor created by the upheaval flooded into the days and weeks that followed, and it earned the name "operation dechoukaj". A survivor of that chaotic day, Michel, is a twelve-year-old boy who presents his understanding of the day's events:

Overnight our country had completely changed. We had fallen asleep under a dictatorship headed by a pudgy thirty-four-year-old man and his glamorous wife. During the night they'd sneaked away [...] Their departure, however, orphaned a large number of loyal militiamen [...] Now the population was going after those militiamen, those macoutes, with the determination of an army in the middle of its biggest battle to date. My cousin Vaval [...] told us how on his way to the bus depot he had seen a group of people tie one of these militiamen to a lamppost, pour gasoline down his throat, and set him on fire (Danticat 2005: 140).

It is frequently the case, with such upheavals, that the reaction to the wrongdoers replicates what was done before. The description of that day shows the trauma of an entire group of people. The chaos, anxiety and despair of that day and many others to follow is explained by Arthur G. Neal in National Trauma and Collective Memory. The author describes how the enduring effects of a national trauma and collective resentments can be expressed in a violent action. He claims that when collective sadness is accompanied by anger, a volatile situation frequently develops (Neal 1998: 5-6). In this case collective anger was directed toward the Duvalier family and the Tonton Macoutes. Enveloped in a sense of rage and hostility, rioters yearned to destroy the physical reminders of the twenty-nine-year Duvalier dictatorship, and to repress painful memories. However, with such actions, justifiable though they are, the effect might be to extend the pain, and the stories from The Dew Breaker make it clear that the memories that haunt Haiti and its people remained. The book seems to offer a solution to deal with the traumatic experience, and to accept the past of Haiti ${ }^{11}$. This solution stands in opposition to dechoukaj, which sought to erase every trace of the Duvalier era from the collective memory of Haitians.

11 Such trauma-writing has clearly figured in recent Haitian Literature (see also Dany Laferrière, or other books by Danticat, e.g. The Farming of Bones). 
The protagonists of The Dew Breaker are caught in the dilemma of denying the events that hurt them so much and proclaiming them aloud to obtain some justice and recognition for the innocent victims. Reading Danticat's book, it can be concluded that the key to overcoming traumatic experience is remembering and commemorating the losses. Silence reflects unresolved trauma, guilt and shame, while speech, however fragmented, facilitates healing and begins the process of resolving trauma. The wife of a reformed murderer, Anne (“The Book of Miracles”), does not want to or cannot speak of her traumatic experiences. She has been haunted by the threat of exposure and she is caught in persistent silence. She refuses to bear testimony to her own traumatic past, and at the same time is trapped in grief and remains alienated from her daughter who recently learned about her father's past. Other characters in The Dew Breaker try to relieve their burden by speaking out about some of the truths that have been torturing them for many years. They can find partial redemption and alleviation of psychic wounds and scars by sharing their stories. This is certainly the case of the group of young women in "The Funeral Singer". Instead of suppressing their memories, Rezia, Mariselle and Freda meet regularly to talk about their troubled past. They are in need of mourning, remembering, reconnecting, and building some sort of community. Showing that the three women need a long time to understand each other, Danticat enhances the idea that overcoming a traumatic experience needs a long process and empathetic companions, but after the exposure and sharing of their traumatic memories, they "slowly parcel out sorrows, each walking out with fewer than [they]'d carried in" (Danticat 2005: 170). One of the victims, Dany, in "Night Talkers", also begins to work through his trauma when he hears stories of the support that his aunt gives to people in her village. He realizes that coming to terms with his past involves helping somebody, and emphasizes the ability to empathize with others who were equally hurt. Only then does he understand that perpetuating violence will not change the suffering he has gone through, and his experience emphasizes that seeking revenge may not be the solution with which to work through traumatic memories. There might appear to be some catharsis in the collective reaction to the Duvalier regime, but individuals still have to confront and somehow quieten their own intensely personal traumas.

Danticat's fiction presents the effects of trauma on the individual and the community, identifies what is destroyed by trauma, and indicates new strategies and sensibilities that will help the characters to recover. It is equally valid for perpetrators, who also suffer from a trauma not very different from that affecting their prey.

The characters in The Dew Breaker seem to answer the rebellious preacher's question that he asked his followers forty years ago in one of his radio sermons encouraging his followers to fight tyrants: "And what will we do with our beasts?" (Danticat 2005: 185). The protagonists find some rituals to pacify their "beasts", their harrowing memories, the pain and grief. They learn to recall in memory the traumatic experience, but also realize that they are living here and now with openings to the future, in which they can find hope and contentment. Some of the characters try to appease their ghosts from the past by being brought into contact with other individuals who experienced catastrophes. It helps them to see their own problems in a new light and to realize that they 
are not alone in having to cope with the burden of trauma. The Dew Breaker offers a solution to deal with the traumatic experience by revisiting and communicating harrowing experience, and not by destroying the memory or remaining silent.

At this point one might ask the question that appears in Margaret Atwood's The Robber Bride: "Who cares why, at this distance? A disaster is a disaster; those hurt by it remain hurt, those killed remain killed, the rubble remains rubble" (Atwood 1993: 3). The same author may be quoted here to answer this question. The disaster, the dead, the rubble must be brought back "into the land of living and allowed to enter time once more - which means to enter the realm of the audience, the realm of the readers, the realm of change" (Atwood 2002: 179-179). Rewriting history, wresting it from the prison of 'the grand narrative' helps give a voice to traumatized individuals and populations. Such texts as Dandicat's become political acts designed to stir the conscience of the people. Personal narratives enable victims to speak truth to power; they are meta-sites for social critique. Further, their recognition in the international community, the unpredictable patterns of official and unofficial dissemination of stories to multiple audiences, the mixed responses to them, contribute to what is developing as a different politics of social change. The multiple forms of remembrance of and witnessing to abuse spur developments in the field of human rights (Schaffer and Smith 2004: 31-32). Literature of trauma may do important work in fostering awareness of and sympathy for different experiences of individuals around the globe. "Literature of trauma is written from the need to tell and retell the story of the traumatic experience, to make it 'real' both to the victim and to the community. Such writing serves both as validation and cathartic vehicle for the traumatized" (Tal 1996: 21). Danticat's protagonists seem to say exactly what Rigoberta Menchú said in her testimonio: “This is my testimony. I didn't learn it from a book and I didn't learn it alone. I'd like to stress that it's not only my life, it's also the testimony of my people. [...] My personal experience is the reality of a whole people" (Menchú 1984: 1). The Dew Breaker acts as a testimony of collective suffering, and it brings Haiti's historical traumas to the attention of a new audience. The author writes of Haiti in English both to "introduce people to Haiti" and to acquaint people like her American-born compatriots with crucial aspects of Haitian history. The Dew Breaker provides access to history that would otherwise be unknown and unrepresented in histories. It also, apparently, seeks to build bridges—or at least create some understanding-between victims and perpetrators, and expands Haiti's community of survivors with sympathetic readers who share the weight of this nation's traumatic experiences. What is more, Danticat transforms stories of brutalization into narratives of hope, which is also hope for Haiti's future.

Not only are the stories from The Dew Breaker fueled by empathy and enlivened by hope, connection, commitment, and affiliation; not only do they call for justice, and for the reader to be more active and more informed; they are also testimonies that help to deal with emerging fear, trauma and repression. For Cathy Caruth, trauma is an experience so intensely painful that the mind is unable to process it normally. She claims that if the memories of the trauma return, they are often nonverbal, and the victim may be unable to describe them with words. In this connection, Cathy Caruth maintains that fiction can "speak" trauma and may have therapeutic potential, 
whereas normal, discursive language cannot. It is partly because, by its very nature, fiction sits at a distance from the actual, raw experiences of human beings - and can thus offer, however briefly, some detachment. Caruth also affirms the significance of writing trauma literature in the process of remembering and communicating the memory of traumatic events (Caruth 1995: 4). Julia Alvarez also believes that readers can immerse in the particular epoch thanks to imagination, and says that "[a] novel is not after all, a historical document, but a way to travel through the human heart" (Alvarez 1995: 324).

Danticat's book forbids forgetting. The stories need to be heard, and for those who tell them there is a redemptive quality. Such stories create a representative voice for victims of political violence and psychological terror who have been silenced. They seem necessary for the process of reburial and grieving, and they can promote healing and solidarity among disaffected groups and expand human capacity for empathy (Mullins 2008: 4-12). To use Homi Bhabha's words from his Oxford Amnesty Lecture: "the quest for freedom and solidarity_draw on the emotions, the imagination, vivid images and moving narratives" (Bhabha 2003:161), and such narratives have "the creative potential to transform human relations and historical disasters" (Bhabha 2003: 161).

\section{REFERENCES}

Abbott, Elizabeth. 1988. Haiti. The Duvaliers and Their Legacy. London: Robert Hale.

Alvarez, Julia. 1995. In the Time of the Butterflies. New York: Plume.

Atwood, Margaret. 1993. The Robber Bride. New York: Anchor Books.

Atwood, Margaret. 2002. Negotiating with the Dead. A Writer on Writing. Cambridge: Cambridge University Press.

Bellamy, Maria Rice. 2012. More Than Hunter or Pray: Duality and Traumatic Memory in Edwidge Danticat's The Dew Breaker, MELUS, Volume 37, Number 1 (Spring). 177-197.

Bhabha, Homi. 2003. On Writing Rights. In: Matthew J. Gibney (ed.), Globalizing Rights: The Oxford Amnesty Lectures 1999. 160-183. Oxford: Oxford University Press.

Caruth, Cathy. 1995. Introduction. In: Cathy Caruth (ed.), Trauma. Explorations in Memory. Baltimore: The Johns Hopkins University Press.

Caruth, Cathy. 1996. Unclaimed Experience. Trauma, Narrative, and History. Baltimore: The Johns Hopkins University Press.

Coupeau, Steeve. 2008. The History of Haiti. Westport. Greenwood Press.

Craft, Linda J. 1997. Novels of Testimony and Resistance From Central America. Gainesville, University Press of Florida

Danticat, Edwidge. 2005. The Dew Breaker. New York: Vintage Books.

Danticat, Edwidge. 2004. Grappling With Haiti's Beasts, interview with Dana Rousmaniere, The Atlantic, June http://www.theatlantic.com/magazine/archive/2004/06/grappling-with-haiti-sbeasts/303391/ (18 March 2016).

Ferguson, James. 1987. Papa Doc, Baby Doc. Haiti and the Duvaliers. Oxford: Basil Blackwell Ltd. Greene, Graham. 2005. The Comedians. London: Penguin Books. 
Ibarrola Armendariz, Aitor. 2010. The Language of Wounds and Scars in Edwidge Danticat's The Dew Breaker, A Case Study in Trauma Symptoms and the Recovery Process, Journal of English Studies, vol. 8. 23-56.

Irr, Caren. 2014. Toward the Geopolitical Novel. U.S. Fiction in the Twenty-First Century. New York: Columbia University Press.

Kakutani, Michiko. 2014. Hiding From a Brutal Past Spent Shattering Lives in Haiti, The New York Times March 10. http://www.nytimes.com/2004/03/10/books/books-of-the-times-hidingfrom-a-brutal-past-spent-shattering-lives-in-haiti.html?_r=0 (8 February 2016).

Menchú, Rigoberta and Elisabeth Burgos-Debray (ed.). 1984. I, Rigoberta Menchú. An Indian Woman in Guatemala, trans. Ann Wright. London: Verso.

Mullins, Greg. 2008. Labors of Literature and of Human Rights, Peace Review: A Journal of Social Justice, Volume 20, Iss. 1. 4-12.

Neal, Arthur G. 1998. National Trauma and Collective Memory. Armonk: M.E. Sharpe.

Shields, David. 2010. Reality Hunger. A Manifesto. London: Hamish Hamilton.

Schaffer, Kay and Sidonie Smith. 2004. Human Rights and Narrated Lives: The Ethics of Recognition. New York: Palgrave, MacMillan.

Spivak, Gayatri Chakravorty and Sarah Harasym (ed.). 1990. The Post-Colonial Critic: Interviews, Strategies, Dialogues. New York: Routledge.

Tal, Kalí. 1996. Worlds of Hurt. Reading the Literatures of Trauma. Cambridge University Press. Valbrun, Marjorie. 2004. Haiti’s Eloquent Daughter, Black Issues Book Review, Vol. 6, Issue 4 JulyAugust. 42-43.

Wilentz, Amy. 2010. The Dechoukaj This Time. The New York Times Feb. 6th. http://www.nytimes.com/2010/02/07/opinion/07wilentz.html?_r=0 (17 August 2016). 